NASA/TM-2011-217003

\title{
Oil-Free Shaft Support System Rotordynamics: Past, Present, and Future Challenges and Opportunities
}

Christopher DellaCorte

Glenn Research Center, Cleveland, Ohio 


\section{NASA STI Program . . . in Profile}

Since its founding, NASA has been dedicated to the advancement of aeronautics and space science. The NASA Scientific and Technical Information (STI) program plays a key part in helping NASA maintain this important role.

The NASA STI Program operates under the auspices of the Agency Chief Information Officer. It collects, organizes, provides for archiving, and disseminates NASA's STI. The NASA STI program provides access to the NASA Aeronautics and Space Database and its public interface, the NASA Technical Reports Server, thus providing one of the largest collections of aeronautical and space science STI in the world. Results are published in both non-NASA channels and by NASA in the NASA STI Report Series, which includes the following report types:

- TECHNICAL PUBLICATION. Reports of completed research or a major significant phase of research that present the results of NASA programs and include extensive data or theoretical analysis. Includes compilations of significant scientific and technical data and information deemed to be of continuing reference value. NASA counterpart of peer-reviewed formal professional papers but has less stringent limitations on manuscript length and extent of graphic presentations.

- TECHNICAL MEMORANDUM. Scientific and technical findings that are preliminary or of specialized interest, e.g., quick release reports, working papers, and bibliographies that contain minimal annotation. Does not contain extensive analysis.

- CONTRACTOR REPORT. Scientific and technical findings by NASA-sponsored contractors and grantees.
- CONFERENCE PUBLICATION. Collected papers from scientific and technical conferences, symposia, seminars, or other meetings sponsored or cosponsored by NASA.

- SPECIAL PUBLICATION. Scientific, technical, or historical information from NASA programs, projects, and missions, often concerned with subjects having substantial public interest.

- TECHNICAL TRANSLATION. Englishlanguage translations of foreign scientific and technical material pertinent to NASA's mission.

Specialized services also include creating custom thesauri, building customized databases, organizing and publishing research results.

For more information about the NASA STI program, see the following:

- Access the NASA STI program home page at http://www.sti.nasa.gov

- E-mail your question via the Internet to help@ sti.nasa.gov

- Fax your question to the NASA STI Help Desk at $443-757-5803$

- Telephone the NASA STI Help Desk at 443-757-5802

- Write to: NASA Center for AeroSpace Information (CASI) 7115 Standard Drive Hanover, MD 21076-1320 
NASA/TM-2011-217003

\section{Oil-Free Shaft Support System Rotordynamics: Past, Present, and Future Challenges and Opportunities}

Christopher DellaCorte

Glenn Research Center, Cleveland, Ohio

Prepared for the

The 8th International Conference on Rotor Dynamics

sponsored by the International Federation for the Promotion of Mechanism and Machine Science (IFToMM)

Seoul, Korea, September 12-15, 2010

National Aeronautics and

Space Administration

Glenn Research Center

Cleveland, Ohio 44135 
Trade names and trademarks are used in this report for identification only. Their usage does not constitute an official endorsement, either expressed or implied, by the National Aeronautics and Space Administration.

Level of Review: This material has been technically reviewed by technical management.

Available from

NASA Center for Aerospace Information 7115 Standard Drive

Hanover, MD 21076-1320
National Technical Information Service 5301 Shawnee Road Alexandria, VA 22312

Available electronically at http://www.sti.nasa.gov 


\title{
Oil-Free Shaft Support System Rotordynamics: Past, Present, and Future Challenges and Opportunities
}

\author{
Christopher DellaCorte \\ National Aeronautics and Space Administration \\ Glenn Research Center, \\ Cleveland, Ohio 44135
}

\begin{abstract}
Recent breakthroughs in Oil-Free technologies have enabled new high-speed rotor systems and turbomachinery. Such technologies can include compliant-surface gas bearings, magnetic bearings, and advanced solid lubricants and tribo-materials. This presentation briefly reviews critical technology developments and the current state-of-the-art, emerging Oil-Free rotor systems and discusses obstacles preventing more widespread use. Key examples of "best practices" for deploying Oil-Free technologies will be presented and remaining major technical questions surrounding Oil-Free technologies will be brought forward.
\end{abstract}

\section{Nomenclature}

$\begin{array}{ll}\mathrm{DN} & \text { bearing surface velocity parameter } \\ \mathrm{W} & \text { shaft load } \\ \mu & \text { fluid viscosity } \\ \mathrm{W}_{\mathrm{LC}} & \text { load capacity at speed } \\ 0 & \text { journal bearing performance coefficient }\left(\mathrm{lbs} / \mathrm{in} .{ }^{3} / \mathrm{k}_{\mathrm{rpm}}\right) \\ D_{t} & \text { thrust Bearing performance coefficient }\left(\mathrm{lbs} / \mathrm{in} .{ }^{3} / \mathrm{k}_{\mathrm{rpm}}\right) \\ \mathrm{L} & \text { bearing axial length (inches) } \\ \mathrm{D} & \text { shaft diameter (inches) } \\ \mathrm{D}_{\mathrm{m}} & \text { thrust runner median diameter (inches) } \\ w & \text { thrust foil radial extent, width (inches) } \\ \mathrm{K}_{\mathrm{rpm}} & \text { shaft speed in thousands of rpm }\end{array}$

\section{Introduction}

Oil-lubricated rotor support technologies, based upon fluid film and rolling element type bearings, have been an industrial mainstay for centuries and have served society well. Their reliability and high performance with respect to extreme load capacity and their demonstrated long life have enabled them to appropriately dominate most mechanical systems. Ubiquitous examples include: internal combustion engines, power plant turbines, fluid compressors, and electric motors. Decades of productive research, development and experience have resulted in well-understood and accepted rules for successful application and a myriad of specific designs of these machine elements for particularly challenging applications (Ref. 1). This positive experience with conventional rotor support technologies has also had a secondary effect; the diminished awareness of the vital role rotor support technologies play in the overall success and performance of rotating systems. Such a lack of understanding for and appreciation of conventional rotor support technologies is to be expected and to a limited extent acceptable provided that new machines do not push bearing technologies beyond the well established and proven design space.

When new machines, however, go beyond the norm with respect to rotor speed, temperature or other factors, closer attention must be paid to the rotor support system including the consideration of alternate bearing technologies. In this paper, Oil-Free rotor support technologies are examined within a framework 
of their ability to enable the design and deployment of new machines with expanded capabilities. Recent advances, particularly for compliant-surface foil-gas bearings, high temperature solid lubricants and hybrid electromagnetic-gas bearings, are reviewed and a recommended technical path is given for risk mitigation in the development of new machines. Lastly, the remaining technical challenges facing the deployment of Oil-Free technologies are examined.

\section{Foil Gas Bearings-Operating Principles}

Compliant-surface foil-gas bearings are a class of hydrodynamic bearings that use the ambient gas as their working fluid and thus require no dedicated lubrication system. Their hydrodynamic fluid film is formed between the moving shaft surface and a flexible bearing surface typically made from several layers of sheet metal foils. Figure 1 depicts the common bump type of foil bearing.

Foil bearings can be configured as journal or thrust bearings supporting radial or axial shaft loads, respectively as shown in Figure 2.

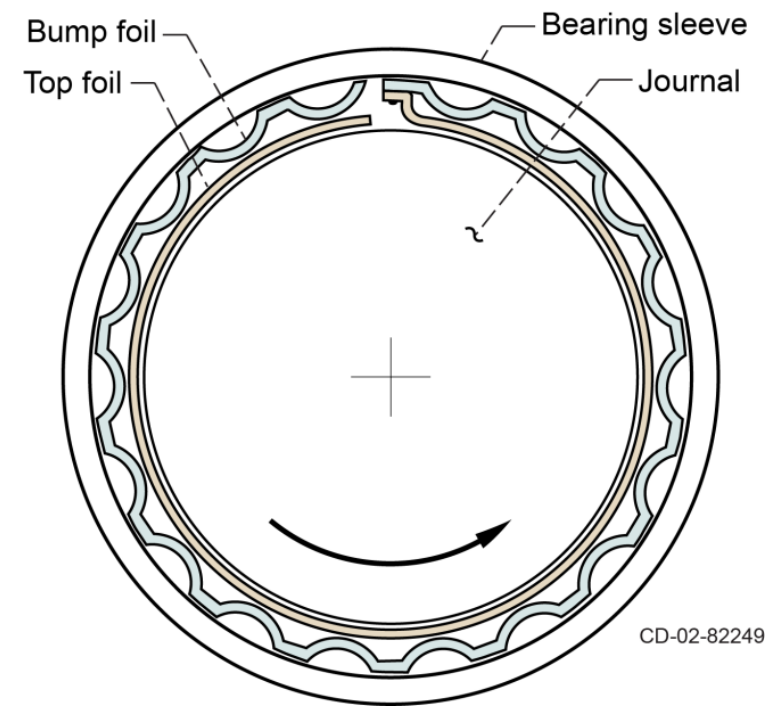

Figure1.-Cross section view of a simple bump type radial foil bearing.

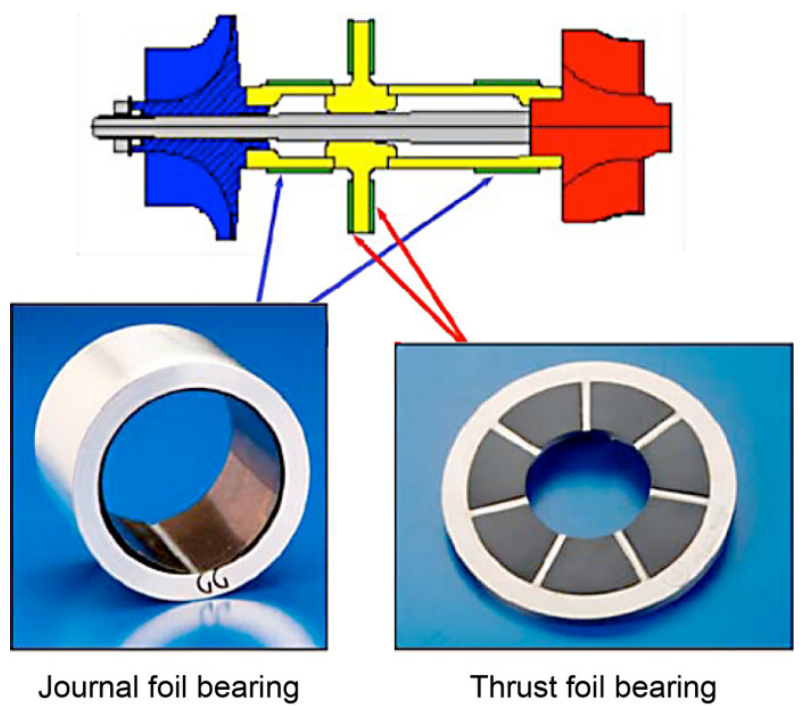

Figure 2.-Journal and thrust foil bearings used to control radial and axial shaft motion, respectively. 
The dominant characteristic of foil-gas bearings is that they float on a self-generated fluid film during normal operation but experience a brief period of dry sliding contact during low speed operation (i.e., start-up, shut-down). The bearing geometry and fluid film thickness depend upon the establishment of equilibrium between the gas film pressure and the elastic deflection of the foil surface and its underlying spring support structure (Ref. 2). During operation, dynamic rotor motions cause fluctuations in the film pressure and commensurate, albeit minute, motions in the foils. This causes internal sliding contact within the bearing structure and contributes a coulomb damping effect to the system (Ref. 3). Thus, in a sense, a foil bearing is both a bearing and a damper. The compliant nature of the bearing also allows it to respond to and accommodate thermal and mechanical distortions much more so than traditional rigid gas bearings. These salient features of foil-gas bearings have long been known.

In a 1969 review of gas bearings, W.R. Gross wrote "Foil bearings were evolved to minimize instability problems, reduce manufacturing tolerances, and permit adaptation of the bearing to changes in shaft diameter caused by centrifugal force or temperature gradients. The fluid film between the shaft and foil is likely to have a greater stiffness than the foil itself" (Ref. 4). The subsequent four decades of research and development in foil bearings has largely reinforced Gross' summary and must be kept first and foremost in mind when integrating foil bearings into new rotor systems.

With this as a backdrop, it is apparent that foil bearing load capacity and dynamic properties are governed largely by the low viscosity nature of the lubricant. This brings both advantages and challenges to systems built using such rotor supports. The primary advantage of gas bearings is the simplification possible through the elimination of the oil system combined with the ability to operate bearings at higher speeds and temperatures. The primary challenge is to develop innovative machine designs that can take advantage of the performance characteristics of foil bearings while accommodating their performance shortcomings (Ref. 5).

Foil bearings provide very modest load capacity, stiffness and damping compared to conventionally supported systems. One can expect stiffness and damping to be an order-of-magnitude lower than comparably sized oil-lubricated bearings. On the other hand, friction can be lower especially at high rotational speeds and foil bearings have no intrinsic DN speed limitations, as do rolling element type bearings. Foil bearing load capacity is heavily influenced by speed as well. At high speeds, foil-gas bearings exhibit comparable or even higher load capacity than rolling-element bearings but have limited capability at low speeds (Ref. 6).

These characteristics of foil-gas bearings dictate that their successful application occurs when a rotor system is designed around the bearing capabilities in contrast to the now common practice of first designing the aero-components and determining speeds and loads from which the rotor design and bearing requirements follow. Later in this paper, a recommended four-step rotor system development path will be described which has been effective in adopting Oil-Free technologies for new high speed machines (Ref. 7).

\section{Foil-Gas Bearings-Solid Lubricants}

Foil bearings experience brief sliding contact during start-up and shutdown when surface velocity and hydrodynamic gas film pressure is insufficient to promote a fully developed lubricant film. Solid lubricants are needed to mitigate wear of the foils, reduce friction and maintain smooth surfaces required by gas bearings. Solid lubricants also provide a secondary function as a sacrificial, non-structural material that enables the development of conforming surfaces through the wear-in process (Ref. 8). This characteristic is vitally important for bearings with non-optimal geometries or undesirable manufacturing variances. Towards this end, soft solid lubricants are typically applied to the foil surface and hard wearresistant coatings are used on shaft surfaces. An alternative approach employs composite shaft coatings that are simultaneously reservoirs for solid lubricants and offer wear protection by also containing harder phases. Figure 3 depicts the system nature of foil and shaft coatings used for the solid lubrication of foilgas bearings. 


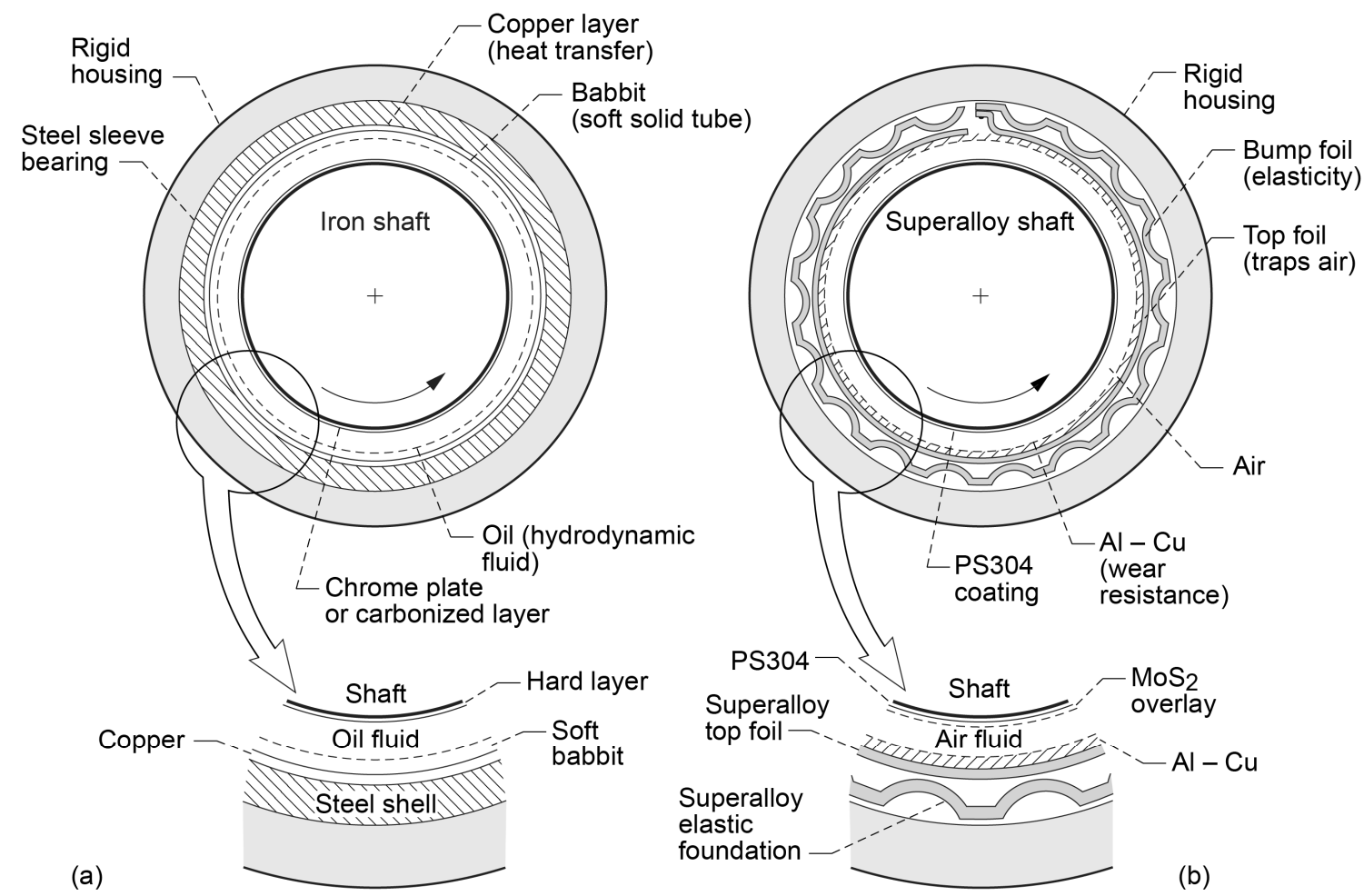

Figure 3.-System of solid lubricants is used for foil bearings analogous to the system used for conventional oil-lubricated bearings (Ref. 8).

Foil coating development and performance is well documented in the literature and can be broadly classified depending upon temperature requirements of an application. For low temperatures up to $300{ }^{\circ} \mathrm{C}$ thin polymer films made from PTFE (polytetrafluoroethylene), polyimide and polyamides are traditionally employed. These films are often doped with solid lubricants such as graphite, molybdenum disulfide and boron nitride to further reduce friction and enhance life. For temperatures above $300{ }^{\circ} \mathrm{C}$, foil coatings can either be strictly hard wear-resistant ceramics such as aluminium oxide and titanium carbide or metalceramic-solid lubricant composites deposited by spraying, dipping or through electrochemical techniques followed by high temperature curing (Ref. 9). Such films are often mechanically burnished (polished) to achieve more uniform thickness and smooth surface finishes. Whatever techniques and materials used, the polymer coatings yield low friction and long life at a low cost and are thus preferred whenever temperatures are not extreme.

For good solid lubrication to occur, the foil's mating surface must be engineered appropriately. When operating against polymer foil coatings, the mating surface is typically coated with chrome, either hard chrome or thin dense chrome. Chrome plating results in a smooth and durable finish that resists galling with the foil in the event of a foil coating wear through. When high temperatures are encountered, either bare or hard coated foils are operated against ceramic or composite shaft coatings like the NASA developed PS300 and PS400 plasma sprayed coatings. Such approaches offer moderate friction levels and the ability to operate foil bearings to $650{ }^{\circ} \mathrm{C}$ or higher (Refs. 10 and 11).

\section{Foil-Gas Bearings-Performance Characteristics}

Experimental and analytical data combined with experience with operating Oil-Free turbomachinery has given rise to estimation rules for foil bearing performance. These "Rules-of-Thumb" (ROT) can be used as a starting point from which to develop a new machine design. The ROT for foil bearing load capacity was clearly established by comparing bearing structural design to measured performance and the following linear relationship between bearing size, speed, design and load capacity follows (Ref. 6): 


$$
\mathrm{W}_{\mathrm{LC}}=\mathcal{D}(\mathrm{LD}) \mathrm{DK}_{\mathrm{rpm}}
$$

The symbols in Equation (1) are defined in the nomenclature section. A few specific examples follow to illustrate the current understanding of journal bearing scalability effects (Ref. 12).

A $100 \mathrm{~mm}$ diameter $(D=1, \mathrm{~L} / \mathrm{D}=1)$ bearing operating at $20,000 \mathrm{rpm}(2 \mathrm{MDN})$ would be expected to carry about 1,280 lbs $(\sim 6 \mathrm{kN})$ maximum load. Bearings of this size have been produced and tested. Experimental data from the literature (Ref. 21) corroborates the load capacity ROT estimates for such bearings and is considered within current state-of-the-art.

Extending the ROT approach, a bearing twice the diameter and twice the length $(200 \mathrm{~mm})$ would support eight times the load $(10000 \mathrm{lbs}, 4800 \mathrm{kN})$ and be operating at approximately the previously established DN speed limit (4 million). Based upon these static load (14 to $55 \mathrm{kPa}$ ) considerations alone, the $100 \mathrm{~mm}$ diameter journal bearings used in the above example (two per rotor) can support rotors from 300 to $1200 \mathrm{~N}$ (64 to $256 \mathrm{lbs}$ ). Rotors of this size are typical for air compressors in the 75 to $400 \mathrm{~kW}$ (100 to $500 \mathrm{hp}$ ) range and small business class turbofan engines (1,000 lbs, $5000 \mathrm{~N}$ thrust levels).

Thrust foil bearings ascribe to the same underlying physics as journal bearings and can be modeled in a similar fashion (Ref. 13). Using an analogous approach, the thrust bearing load capacity ROT is as follows:

$$
\mathrm{W}_{\mathrm{LC}}=\boldsymbol{D}_{t}\left(w \mathrm{D}_{\mathrm{m}}\right) \mathrm{D}_{\mathrm{m}} \mathrm{K}_{\mathrm{rpm}}
$$

where the value $w$ represents the radial pad extent (outer radius-inner radius) and the $\mathrm{D}_{\mathrm{m}}$ represents the median bearing diameter. Though load capacity performance data is more limited than journal bearing data, when using Equation (2), one finds performance coefficients ranging from 0.02 to 0.13 or about 5 to 10 times smaller than those for journal bearings. Such modest thrust bearing load capacity levels may be due to developmental immaturity or possibly due to thermal management challenges inherent in thrust bearings. One such challenge is that lubricating fluid ejected from a pad feeds directly into the following pad making bearing cooling difficult. It may also be that thermal and centrifugal distortion is more pronounced in thrust runners because their size is often larger than journal bearings. Whatever the reasons, thrust-bearing performance remains a characteristic that must be accommodated in machine designs.

Though not as well established, similar rules (ROT's) are being developed for bearing stiffness and damping. Foil-gas bearing stiffness and damping are characterized by non-linearity, frequency and temperature dependence and no well-accepted methods for measurement. Predictive tools are becoming available that enable dynamic property estimation based upon bearing structural design and operating parameters but these are in their early development. For preliminary machine design an experimentally based "first-order" approximation for stiffness and damping can be made by assuming that broad ranges for these parameters exist depending upon bearing loading and operating condition.

Stiffness for foil bearings can be expected to be similar for all bearings when normalized for bearing size (projected area) because the gas film properties (hydrodynamic pressures) are similar. Hydrodynamic gas pressures are typically one to five atmospheres. To function properly, a foil bearing structure must be sufficiently deflected by such low pressures and this necessitates rather modest structural stiffness. In practice, this unit stiffness is around $6 \mathrm{MN} / \mathrm{m}$ for each square $\mathrm{cm}$ of projected bearing area $\left(\mathrm{D}^{*} \mathrm{~L}\right)$. Lightly loaded bearings exhibit a reduction in this value of about 50 percent and heavily loaded bearings see this value increased by about 50 percent. Thus the range one can expect for stiffness is about 3 to $9 \mathrm{MN} / \mathrm{m} / \mathrm{cm}^{2}$ (2500 to $7500 \mathrm{lbs} / \mathrm{in} . /$ in. $^{2}$ ) (Ref. 14). Bearings operating near their load capacity limit may provide static and dynamic stiffness values one to two times higher than this range but such operation is not typical and can suffer from thermal instability and rapid failure (Ref. 15).

Damping in foil bearings is due mostly to a sliding friction dissipation mechanism between foil layers and between the sleeve and foils where contact occurs. Since such coulomb damping is predicated on the low amplitude rubbing motion between compliant, lightly loaded components (foils) the dampening effect is modest compared to fluid film (oil) dampers. Further, the energy dissipation that results must be managed via conduction or convective cooling to maintain thermal equilibrium. For these reasons, the observed damping action of a foil gas bearing is typically one to two orders-of-magnitude lower than oillubricated sleeve bearings and squeeze film dampers but higher than a hard mounted ball bearing. 
Experimental values range from 100 to $1800 \mathrm{~N}-\mathrm{s} / \mathrm{m} / \mathrm{cm}^{2}\left(0.5\right.$ to $10 \mathrm{lbs} / \mathrm{in} . /$ in. $\left.^{2}\right)$ with the most typical values being around $200 \mathrm{~N}-\mathrm{s} / \mathrm{m} / \mathrm{cm}^{2}$ (Ref. 16). Again, these values have been normalized by the bearing size $\left(D^{*} \mathrm{~L}\right)$ in $\mathrm{cm}^{2}$. The large scatter of damping values is partly due to the lack of uniformity in the measurement technique and the wide range of support structures utilized by foil bearings (i.e., bump foils, lever springs, wire mesh, visco-elastic layers, etc.).

Utilizing these rules, one can layout (design) a rotor system effectively sizing the bearings and determining general performance characteristics. Bearing load capacity margin, lift-off speed, shaft orbits and critical speed margins can then be roughly assessed. This type of first order analysis is considered to be the first step in a four-step process used for machine development as outlined below.

\section{The Four-Step Process}

The integration of Oil-Free foil air bearing technology into turbomachinery systems is best done via a four-step process consisting of: (1) Rotor layout (arrangement) and concept design feasibility assessment; (2) bearing design and performance verification testing; (3) simulated rotor system testing; and (4) turbomachinery system demonstration. This multi-step approach enables one to tailor the rotor system design to meet the needs of the machine (power levels, mass flow, pressure ratio, etc.) while staying within the limitations of the rotor support technologies (Refs. 7, 17, and 18). Since Oil-Free bearing technologies differ significantly in their characteristics compared to conventional bearings, they cannot be directly retrofitted into existing machines without an unacceptable risk of failure.

The first step (Step 1) involves conceptual design of the turbomachinery system and development of layouts of the rotating group including identification of major components, bearing locations, and approximate bearing specifications. The feasibility of the concept is analytically assessed through comparison of the required bearing performance with the available foil bearing technology level. Also, there are opportunities for conceptual design iteration to adjust the design layout for system level improvements (Ref. 19). If the concept cannot be shown to be feasible with foil bearings then this step is the end of the process. Figure 4 shows a typical rotordynamics model prepared in Step 1 to assess system stability and feasibility during a design layout trade study.

Once the feasibility of the system is established a foil bearing development and test verification (Step 2) is started. Foil bearings are sized and designed to meet the performance requirements established by the conceptual design (Ref. 14). The bearings are tested and evaluated as individual bearing components in laboratory test rigs to verify adequate load support at the required speed and temperature conditions. In addition to experimental verification of bearing performance, a number of computer-based tools are emerging for foil bearing performance prediction (Ref. 20). Though in their infancy, these tools are useful in exploring the bearing design space prior to bearing manufacture and testing. If the bearings cannot meet the performance requirements then either the turbomachinery system must be reconfigured or more development is needed.

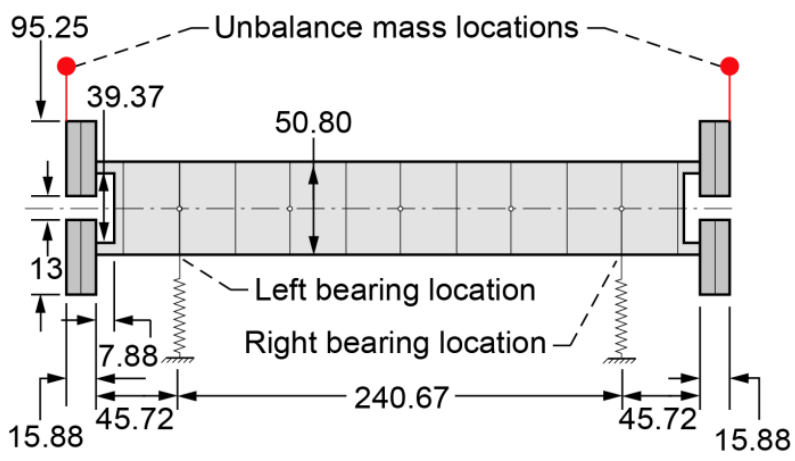

Figure 4.--Rotordynamics layout model used to assess system feasibility based upon critical speeds, required damping, bearing loads and orbits. 


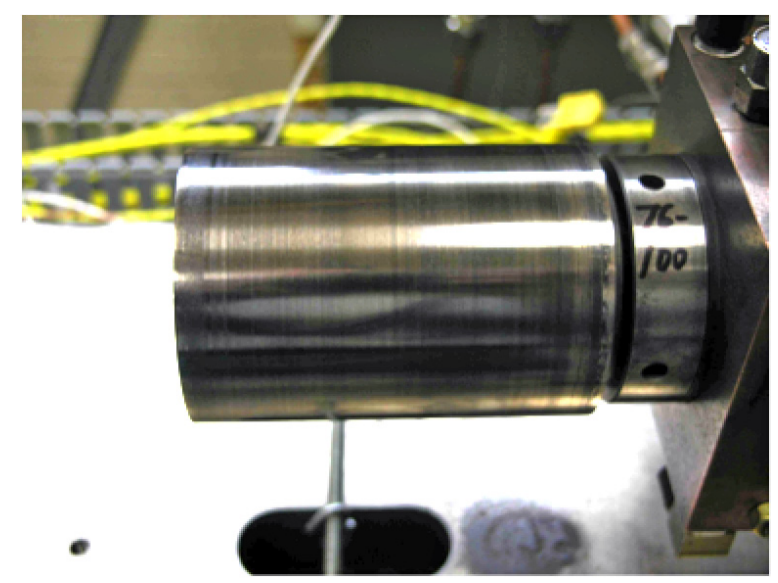

Figure 5.-Foil bearing shaft sustained no damage even during extended operation below the lift-off speed under heavy load and good solid lubrication (Ref. 21).

When extending Oil-Free technologies to larger rotors other challenges surface like starting heavilyloaded, large diameter foil bearings that may undergo extended low speed operation during start-up. Such issues are best addressed in (Step 2 of the four-step process) bearing characterization research. A good example of this Step 2 bearing characterization is captured in a recent paper on the initial starting considerations for foil bearings intended for rotorcraft engines (Ref. 21). In that work, a large (76 mm diameter, $89 \mathrm{~mm}$ long) journal bearing was subjected to a $270 \mathrm{~N}$ static load and slowly accelerated to $15,000 \mathrm{rpm}$ over a $30 \mathrm{sec}$ period to simulate the starting of a rotorcraft engine. Despite concerns that such low speed operation, below and just above the lift-off speed, would physically damage the bearing surfaces, no problems were encountered. Extending the operation (10 min) at a constant speed (3000 rpm) below the lift-off speed to simulate engine windmilling did not result in damage as long as good solid lubrication was provided. Figure 5 shows the condition of the shaft following this testing. These results add valuable and relevant information to the system design process in that start torque and shaft acceleration requirements can be assessed prior to system demonstration.

Following verification of individual bearing performance, the next step (Step 3) is a simulated rotor system test (Refs. 22 and 23). A simulated rotor is fabricated to incorporate representative masses and inertias of the actual rotating group aerodynamic components (compressors and turbines). The simulated rotor system is tested using the prototype foil air bearings to verify rotordynamic stability and performance. This step is also an opportunity to explore operational limits such as bearing misalignment and sensitivity to rotor imbalances in a controlled test environment. Figure 6 depicts a test rig used to experimentally examine shaft rotordynamics to support Step 3 activities.

Finally, after completing concept feasibility, bearing testing, and rotor simulator testing, the Oil-Free turbomachinery system is ready for a system level technology demonstration (Step 4) of the actual hardware assembly.

Using this process Oil-Free technology was successfully demonstrated in an Oil-Free turbocharger for a heavy-duty truck diesel engine (Refs. 24 and 25). The Oil-Free turbocharger demonstration project was triggered by the confluence of four factors: (1) the doubling of foil bearing load capacity via better structural design; (2) the emergence of high temperature solid lubricant coatings tailored for foil bearings; (3) the availability of foil bearing test rigs to verify bearing performance; and (4) having had established a four step hardware development process for risk mitigation. 


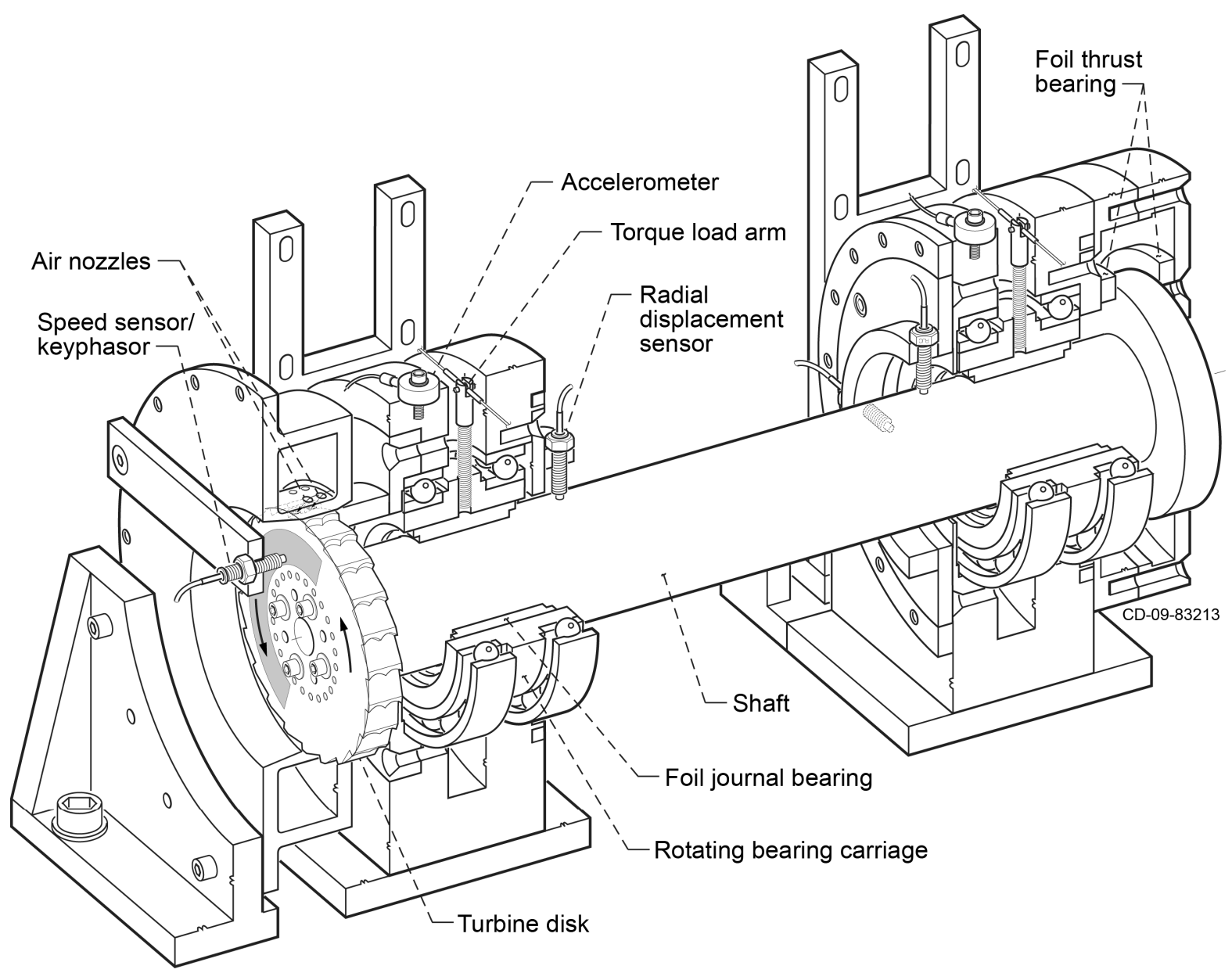

Figure 6.-Oil-Free rotordynamics shaft test rig used to verify rotor support technology prior to system level demonstration (Step 3) (Ref. 22). 


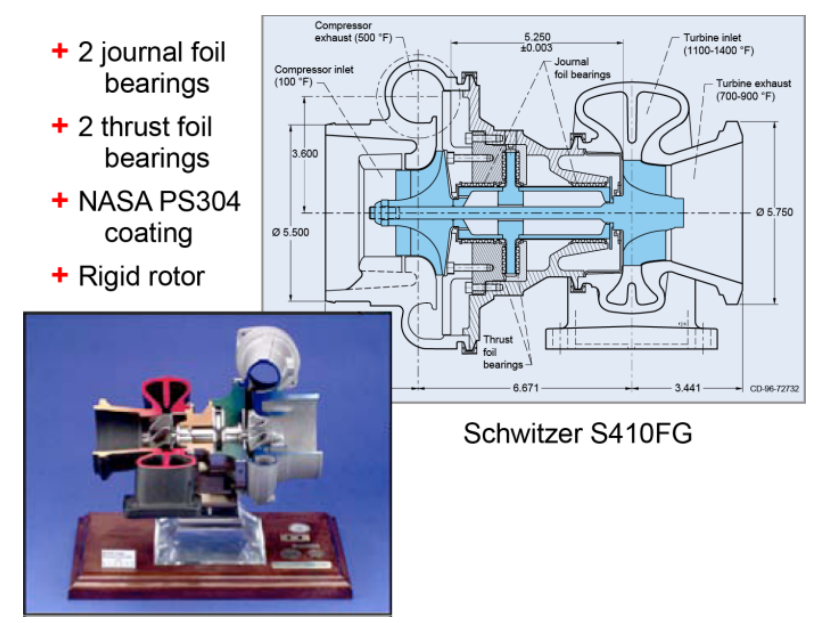

Figure 7.-Cutaway photograph of the NASA OilFree turbocharger (Ref. 25).

NASA's Oil-Free turbomachinery team lead the industry effort that combined the foil bearings of Mechanical Technology Incorporated (later the effort was transferred to Mohawk Innovative Technologies), the turbocharger technology of Schwitzer Corporation (now Borg-Warner Automotive), and the diesel technology of Caterpillar Corporation. Under this project, long-life foil bearings were demonstrated at temperatures over $650^{\circ} \mathrm{C}$, and to speeds of $120,000 \mathrm{rpm}$. The Oil-Free turbocharger, shown in Figure 7, was demonstrated in early 1999 and well publicized through magazine articles, peerreviewed journal papers and conference proceedings (Ref. 25). Further, the successful outcome validated the use of the Four-Step Process for managing risk in deploying Oil-Free technologies to new machines. The pathfinder turbocharger spurred industrial development programs in the US and abroad. To help meet these program needs, reports have been written that document foil bearing design and manufacturing techniques (Refs. 13 and 14). Figure 8 captures the current state-of-the-art very well by detailing the first known production patent for an Oil-Free turbocharger (Ref. 26). Further turbocharger development in Korea has quantified that Oil-Free turbochargers exhibit a significant reduction in friction losses versus conventional machines, with up to 10 percent overall efficiency improvements (Ref. 27). The development of turbochargers signifies that many important fundamental milestones for Oil-Free turbomachinery have been realized. Foil bearing design tools, bearing manufacturing methods, and solid lubricant coatings with long-life at low and high temperatures have been proven. Practical commercial rotordynamic modeling tools and software packages exist that predict, reasonably well, the critical speeds, bearing properties and shaft dynamic behavior for foil bearing supported systems (Ref. 20). In addition, the successful commercialization or demonstration of large compressors ( $300 \mathrm{~kW}$ class), microturbines (30 to $200 \mathrm{kWe}$ ), cryogenic turbines and air cycle machines signals that the technology base for Oil-Free turbomachinery is strong. More development is needed to apply the technologies to new applications. 


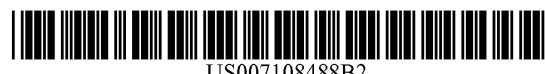

(12) United States Patent Larue et al. $\begin{array}{ll}\text { (10) Patent No.: } & \text { US 7,108,488 B2 } \\ \text { (45) Date of Patent: } & \text { Sep. 19, } 2006\end{array}$

(45) Date of Patent:

$4,850,721 \mathrm{~A} * 7 / 1989$ Malabre et al. ............. 384/106 $5,014,518 \mathrm{~A} * 5 / 1991$ Thomson et al. ..............60/684 $5,102,305 \mathrm{~A} * 4 / 1992$ Bescoby et al. ............ 417/407 5,131,807 A $\quad 7 / 1992$ Fischer et al. ............... 417/407 $5,140,968 \mathrm{~A} * \quad 8 / 1992$ Doan ......................... 123/572 $5,427,455 \mathrm{~A} * 6 / 1995$ Bosley ...................... 384/103 $5,529,464 \mathrm{~A} * 6 / 1996$ Emerson et al. ........... 384/106

$\begin{array}{lll}5,857,332 \mathrm{~A} & 1 / 1999 & \text { Johnston et al .............. 417/407 } \\ 5,890,881 \mathrm{~A} * & 4 / 1999 & \text { Adeff ........................ 417/407 }\end{array}$

(Continued)

FOREIGN PATENT DOCUMENTS

GB $2335710 \quad 9 / 1999$ patent is extended or adjusted under 35 U.S.C. 154 (b) by 0 days

(Continued) OTHER PUBLICATIONS

(22) Filed: Mar. 26, 2004

(65)

Prior Publication Data US 2005/0210875 A1 $\quad$ Sep. 29, 2005

(51) Int. Cl.

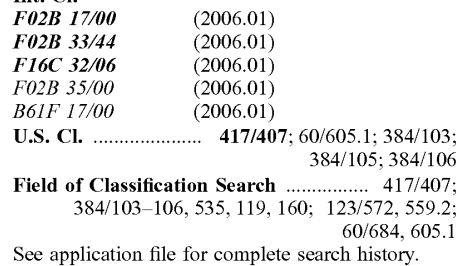
(56)

$$
\text { References Cited }
$$
U.S. PATENT DOCUMENTS
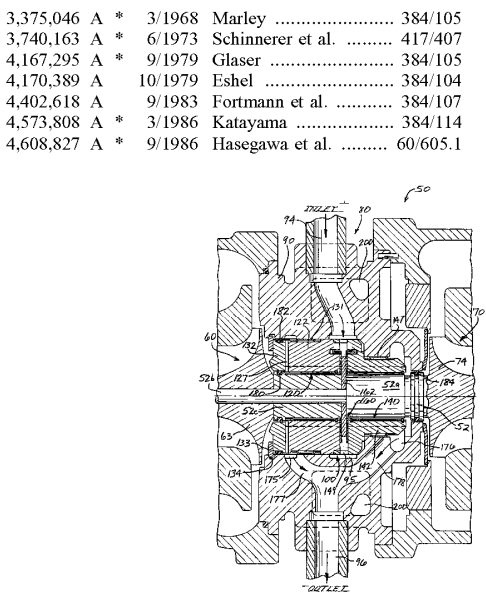

Figure 8.-Production patent for an Oil-Free turbocharger (Ref. 26). 


\section{Future Challenges and Directions}

As rotors become heavier and bearings become larger, several characteristics of foil bearings present challenges. Among these are high-start torque requirements, limited damping and limited low speed load capacity (Ref. 21). Recent work with large $(75 \mathrm{~mm}$ diameter) journal bearings operating under high static loads $(75 \mathrm{kPa})$ has shown that durable low friction coatings and careful minimization of spring preload forces can allow bearings to survive even low shaft acceleration during prolonged start-up periods. Notwithstanding, long-term applications of large foil bearings for heavy rotors could benefit from hydrostatic or electromagnetic load sharing, especially during low speed operation.

Perhaps more important than load capacity and durability, gas bearings lack the rigidity of conventional bearings and provide orders-of-magnitude lower damping than oil-lubricated technologies. Emerging design rules-of- thumb for foil bearing stiffness and damping will certainly aid in designing systems that can accommodate technological shortcomings. Nonetheless, some high performance machine designs may not be possible without the additive benefits of hybridization of rotor support technologies.

An early demonstration of such a hybrid approach included the side-by-side demonstration of a large (100 mm diameter) foil-magnetic bearing (Refs. 28 and 29). Such concepts have been patented (Refs. 30 and 31) and recent demonstrations indicate that this technology marriage is more capable than either bearing technology alone. Hybridization leads to a "smart" bearing in which the rotor static weight loads can be relieved and active damping can be added via electromagnetics (Ref. 28). Figure 9 depicts the hybrid "smart" bearing approach.

Thrust bearing development will also be needed to handle more challenging Oil-Free machine applications (Ref. 32). Thrust foil bearings operate under the same basic principles as journal bearings but have received generally less investigative and development effort. This is partly because many machines can be designed with minimal thrust load requirements via aerodynamic pressure balancing. Thus, foil thrust bearing performance has not greatly limited machine design as has journal bearing performance. Also, more emphasis has been placed on enhanced rotordynamics that are largely controlled by journal bearings not thrust bearings. It is perhaps for these reasons that thrust bearing load capacity lags that of journal bearings by approximately a factor of 5 to 10 . Since designing machines in which axial shaft (thrust) loads are minimized can be an obstacle to efficiency and performance, improved thrust bearing technology remains a formidable challenge to the extension of Oil-Free Turbomachinery.

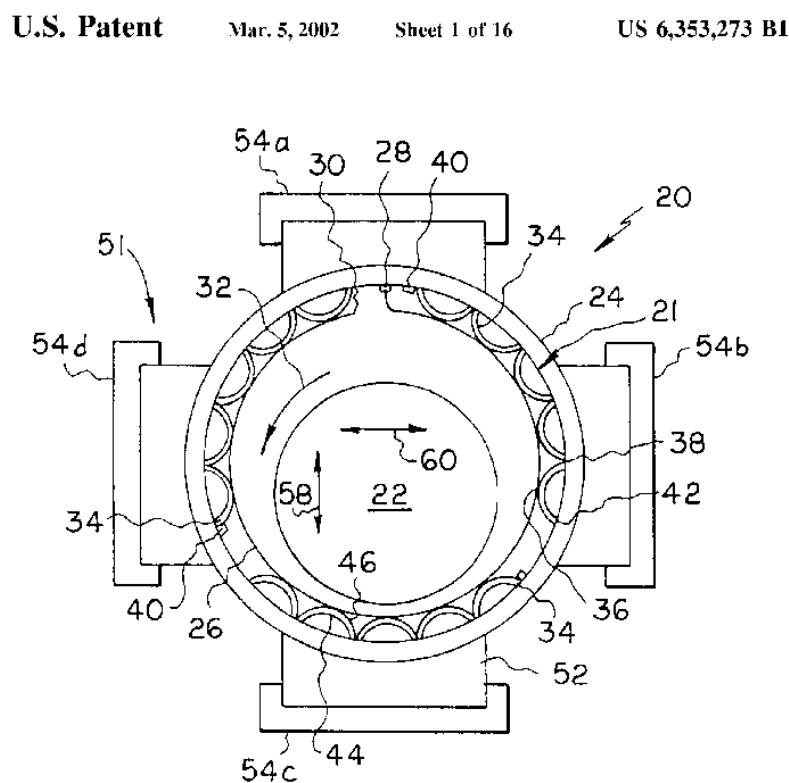

Figure 9.-Early hybrid foil-magnetic bearing concept that nests the foil bearing inside electromagnetic coils to create a "smart" bearing (Ref. 30). 


\section{Summary Remarks}

Oil-Free rotor support technology has progressed greatly in the five decades since the first compliant surface gas foil bearings were developed. While the reliance on thin gas films as their working fluid leads to modest performance characteristics, doing so also enables design of machines with higher speed and temperature capabilities and reduced or even eliminated rotor system maintenance requirements.

To date, Oil-Free rotor support system technology has enabled a broad range of high-speed machinery from air cycle machines, compressors and blowers to turbochargers, microtubines and small gas turbine engines. A four-step process for rotor system design has been articulated and proven to mitigate development risk. Such a formalized development process is vital during the current stage of Oil-Free technology deployment. As the technology becomes better understood, it is expected that more conventional evolutionary extensions of existing rotor system designs will again become the normal practice.

Lastly, it is expected that future systems will involve more complex technology approaches. Hybrid bearing approaches utilizing external pressurization, active thrust load management and electromagnetic devices will evolve to meet the needs for higher performance and larger machinery. Until that time, the current technology will be implemented in ever increasing corners of the high-speed machinery market.

\section{References}

1. Dowson, D.: History of Tribology, Chapter 2, Second Edition, pages 443-507, Professional Engineering Publishing, London, 1998.

2. DellaCorte, C., Radil, K.C., Bruckner, and Howard, S.A.: "A Preliminary Foil Gas Bearing Performance Map," Presented at the STLE Annual Meeting, Calgary, Canada, May 2006, NASA/TM-2006-214343, October 2006.

3. Ku, C.P.R., Heshmat, H.: "Structural Stiffness and Coulomb Damping in Comliant Foil Journal Bearings: Parametric Studies," STLE Transactions, vol. 37, no. 1, January 1994.

4. Gross, W.A.: "A Review of Developments in Externally Pressurized Gas Bearing Technology Since 1959," Journal of Lubrication Technology, January 1969, p. 163.

5. DellaCorte, C. and Valco, M.J.: "Oil-Free Turbomachinery Technology for Regional Jet, Rotorcraft and Supersonic Business Jet Propulsion Engines," Proceedings of the 2003 ISABE Conference, Cleveland, Ohio, AIAA/ISABE \#2003-1182.

6. DellaCorte, Christopher and Valco, Mark J.: "Load Capacity Estimation of Foil Air Journal Bearings for Oil-Free Turbomachinery Applications," Tribology Transactions, vol. 43, no. 4, pp. 795-801, October 2000.

7. Lynch, T.: “Smart Bearing Boosts Air Turbine Efficiency," Design News, November 1993, pp. 101-103.

8. DellaCorte, Christopher; Zaldana, Antonio; Radil, Kevin: "A Systems Approach to the Solid Lubrication of Foil Air Bearings for Oil-Free Turbomachinery," ASME Journal of Tribology, vol. 126, pp. 200-207, January 2004. Also NASA/TM-2002-211482, ARL-TR-2867, October 2002.

9. Bhushan, B.: "High Temperature Self-Lubricating Coatings for Air Lubricated Foil Bearings for Automotive Gas Turbine Engine," NASA CR-159848, April 1980.

10. Lubell, D., DellaCorte, C., and Stanford, M.K.:" Test Evolution and Oil-Free Engine Experience of a High Temperature Foil Air Bearing Coating," Proceedings of GT2006:ASME Turbo Expo 2006, May 8-11, 2006, Barcelona, Spain, paper number GT2006-90572.

11. DellaCorte, C., and Edmonds, B.J.: "NASA PS400: A New High Temperature Solid Lubricant Coating for High Temperature Wear Applications," NASA/TM-2009-215678, August 2009.

12. DellaCorte, C. and Bruckner, R.J.: "Remaining Technical Challenges and Future Plans for Oil-Free Turbomachinery," IGTI paper GT-2010-22086, June 2010.

13. Dykas, B., Bruckner, R.J., DellaCorte, C., Edmonds, B.J., and Prahl, J.M.: "Design, Fabrication and Performance of Foil Gas Thrust Bearings for Microturbomachinery Applications," NASA/TM- 
2008-215-062, ASME Paper GT2008-50377, and ASME Journal of Engineering for Gas Turbines and Power, vol. 131, 012301-1 to 012301-8, January 2009.

14. DellaCorte, C., Radil, K.C., Bruckner, and Howard, S.A.: "Design, Fabrication, and Performance of Open Source Generation I and II Compliant Hydrodynamic Gas Foil Bearings," NASA/TM-2007214691, ARL-TR-4102, and STLE Tribology Transactions, vol. 51, pp. 254-264, 2008.

15. Radil, K.C., and Zeszotek, M.: "An Experimental Investigation Into the Temperature Profile of a Compliant Foil Air bearing,” NASA/TM-2004-213100 and ARL-TR-3200, May 2004.

16. DellaCorte, C.: "Stiffness and Damping Coefficient Estimation of Compliant Surface Gas Bearings for Oil-Free Turbomachinery," NASA/TM-2010-216924, ASME/STLE IJTC 2010-41232.

17. Valco, M.J., and DellaCorte, C.: "Emerging Oil-Free Turbomachinery Technology for Military Propulsion and Power Applications," Proceedings of the ARMY Sciences Conference, Ft. Lauderdale, FL. February 2003.

18. Badgley, R.H., and Reddecliff, J.: "Evaluation of a Gas Lubricated Foil Bearing for Control of Gas Turbine Engine Rotor Critical Speeds," Society of Automotive Engineers paper SAE-751072, November 1975.

19. Howard, S.A., Bruckner, R.J., DellaCorte, C., and Radil, K.C.: "Preliminary Analysis for an Optimized Oil-Free Rotorcraft Engine Concept," NASA/TM-2008-215064, ARL-TR-4398, Proceedings of the American Helicopter Society, AHS Forum 63, Virginia Beach, Virginia, May 2007.

20. Howard, S.A., and San Andres, L.: "A New Analysis Tool Assessment for Rotordynamic Modeling of Gas Foil Bearings,” ASME GT-2010-22508, June 2010.

21. Radil, K.C., and DellaCorte, C.: "Foil Bearing Starting Considerations and Requirements for Rotorcraft Engine Applications," Army Research Report ARL-TR-4873, August 2009.

22. Howard, S.A.: "A New High-Speed Oil-Free Turbine Engine Rotordynamics Simulator Test Rig," NASA/TM-2007-214489, April 2009.

23. Howard, S.A.: "Misalignment in Gas Foil Journal Bearings: An Experimental Study," Journal of Engineering for Gas Turbines and Power, volume 131, March 2009.

24. Howard, S.A.: "Rotordynamics and Design Methods of an Oil-Free Turbocharger," NASA CR-1999208689, January 1999.

25. Heshmat, Hooshang; Walton, II, James F.; DellaCorte, Christopher; Valco, Mark: "Oil-Free Turbocharger Demonstration Paves Way to Gas Turbine Engine Applications," presented at the International Gas Turbine \& Aeroengine Congress \& Exhibition sponsored by the American Society of Mechanical Engineers, Munich, Germany, May 8-11, 2000, 2000-GT-620.

26. LaRue, G.D., Kang, S.G. and Wick, W. (2006), "Turbocharger with Hydrodynamic Foil Bearings," U.S. Patent No. 1,108,488.

27. Lee, Y.B., Park, D.J., and Kim, C.H.; "Stability and Efficiency of Oil-Free Turbocharger with Foil Bearings for SUV, SAE paper 08SFI-0083, 2008.

28. Swanson, E.E., Heshmat, H., and Walton, J.F. II: "Performance of a Foil-Magnetic Hybrid Bearing," Journal of Engineering Gas Turbines Power, vol. 124, issue 2, pp. 375-383, April 2002.

29. Lee, Y.B., Lee S.H., and Kim, S.J.: "Vibration Control and Low Power Consumption of the Combined Smart Bearings," Proceedings of the 4th World Tribology Congress 2009, Kyoto Japan, September 6-11, 2009, paper F-223.

30. Nadjafi, R.H.: "Hybrid Foil/Magnetic Bearing," US Patent \#6,135,640, October 2000.

31. Heshmat, H., Chen, M., and Walton, J.F., III: "Hybrid Foil-Magnetic Bearing," US Patent \#6,353,273, March 2002.

32. Kim, K.S.; "An Experimental Study on the Performance of Air Foil Thrust Bearing for Application to Turbomachinery," Ph.D. Dissertation, Korean Advanced Institute of Science and Technology, Daejon, Korea, December 2006. 


\begin{tabular}{|c|c|c|c|c|c|}
\hline \multicolumn{5}{|c|}{ REPORT DOCUMENTATION PAGE } & $\begin{array}{l}\text { Form Approved } \\
\text { OMB No. 0704-0188 }\end{array}$ \\
\hline \multicolumn{6}{|c|}{$\begin{array}{l}\text { The public reporting burden for this collection of information is estimated to average } 1 \text { hour per response, including the time for reviewing instructions, searching existing data sources, gathering and maintaining the } \\
\text { data needed, and completing and reviewing the collection of information. Send comments regarding this burden estimate or any other aspect of this collection of information, including suggestions for reducing this } \\
\text { burden, to Department of Defense, Washington Headquarters Services, Directorate for Information Operations and Reports (07004-0188), } 1215 \text { Jefferson Davis Highway, Suite } 1204 \text {, Arlington, VA } 22220-4302 \text {. } \\
\text { Respondents should be aware that notwithstanding any other provision of law, no person shall be subject to any penalty for failing to comply with a collection of information if it does not display a currently valid OMB } \\
\text { control number. } \\
\text { PLEASE DO NOT RETURN YOUR FORM TO THE ABOVE ADDRESS. }\end{array}$} \\
\hline \multicolumn{2}{|c|}{$\begin{array}{l}\text { 1. REPORT DATE (DD-MM-YYYY) } \\
01-04-2011\end{array}$} & \multicolumn{3}{|c|}{$\begin{array}{l}\text { 2. REPORT TYPE } \\
\text { Technical Memorandum }\end{array}$} & 3. DATES COVERED (From - To) \\
\hline \multirow{3}{*}{\multicolumn{5}{|c|}{$\begin{array}{l}\text { 4. TITLE AND SUBTITLE } \\
\text { Oil-Free Shaft Support System Rotordynamics: Past, Present, and Future Challenges and } \\
\text { Opportunities }\end{array}$}} & 5a. CONTRACT NUMBER \\
\hline & & & & & 5b. GRANT NUMBER \\
\hline & & & & & 5c. PROGRAM ELEMENT NUMBER \\
\hline \multirow{3}{*}{\multicolumn{5}{|c|}{$\begin{array}{l}\text { 6. AUTHOR(S) } \\
\text { DellaCorte, Christopher }\end{array}$}} & 5d. PROJECT NUMBER \\
\hline & & & & & 5e. TASK NUMBER \\
\hline & & & & & $\begin{array}{l}\text { 5f. WORK UNIT NUMBER } \\
\text { WBS 877868.02.07.03.01.01.04 }\end{array}$ \\
\hline \multicolumn{5}{|c|}{$\begin{array}{l}\text { 7. PERFORMING ORGANIZATION NAME(S) AND ADDRESS(ES) } \\
\text { National Aeronautics and Space Administration } \\
\text { John H. Glenn Research Center at Lewis Field } \\
\text { Cleveland, Ohio 44135-3191 }\end{array}$} & $\begin{array}{l}\text { 8. PERFORMING ORGANIZATION } \\
\text { REPORT NUMBER } \\
\text { E-17536-1 }\end{array}$ \\
\hline \multirow{2}{*}{\multicolumn{5}{|c|}{$\begin{array}{l}\text { 9. SPONSORING/MONITORING AGENCY NAME(S) AND ADDRESS(ES) } \\
\text { National Aeronautics and Space Administration } \\
\text { Washington, DC 20546-0001 }\end{array}$}} & $\begin{array}{l}\text { 10. SPONSORING/MONITOR'S } \\
\text { ACRONYM(S) } \\
\text { NASA }\end{array}$ \\
\hline & & & & & $\begin{array}{l}\text { 11. SPONSORING/MONITORING } \\
\text { REPORT NUMBER } \\
\text { NASA/TM-2011-217003 }\end{array}$ \\
\hline \multicolumn{6}{|c|}{$\begin{array}{l}\text { 12. DISTRIBUTION/AVAILABILITY STATEMENT } \\
\text { Unclassified-Unlimited } \\
\text { Subject Category: } 23 \\
\text { Available electronically at http://www.sti.nasa.gov } \\
\text { This publication is available from the NASA Center for AeroSpace Information, 443-757-5802 }\end{array}$} \\
\hline \multicolumn{6}{|c|}{ 13. SUPPLEMENTARY NOTES } \\
\hline \multicolumn{6}{|c|}{$\begin{array}{l}\text { 14. ABSTRACT } \\
\text { Recent breakthroughs in Oil-Free technologies have enabled new high-speed rotor systems and turbomachinery. Such technologies can } \\
\text { include compliant-surface gas bearings, magnetic bearings, and advanced solid lubricants and tribo-materials. This presentation briefly } \\
\text { reviews critical technology developments and the current state-of-the-art, emerging Oil-Free rotor systems and discusses obstacles } \\
\text { preventing more widespread use. Key examples of "best practices" for deploying Oil-Free technologies will be presented and remaining } \\
\text { major technical questions surrounding Oil-Free technologies will be brought forward. }\end{array}$} \\
\hline \multicolumn{6}{|c|}{$\begin{array}{l}\text { 15. SUBJECT TERMS } \\
\text { Oil-free turbomachinery; Foil bearings; Gas turbines; Propulsion; Hybrid foil-magnetic bearings; Rotordynamics }\end{array}$} \\
\hline \multicolumn{3}{|c|}{ 16. SECURITY CLASSIFICATION OF: } & $\begin{array}{l}\text { 17. LIMITATION OF } \\
\text { ABSTRACT }\end{array}$ & $\begin{array}{l}\text { 18. NUMBER } \\
\text { OF }\end{array}$ & $\begin{array}{l}\text { 19a. NAME OF RESPONSIBLE PERSON } \\
\text { STI Help Desk (email:help@sti.nasa.gov) }\end{array}$ \\
\hline $\begin{array}{l}\text { a. REPORT } \\
\text { U }\end{array}$ & $\begin{array}{l}\text { b. ABSTRACT } \\
\text { U }\end{array}$ & $\begin{array}{l}\text { c. THIS } \\
\text { PAGE } \\
\text { U }\end{array}$ & UU & $\begin{array}{l}\text { PAGES } \\
19\end{array}$ & $\begin{array}{l}\text { 19b. TELEPHONE NUMBER (include area code) } \\
443-757-5802\end{array}$ \\
\hline
\end{tabular}



